\title{
Effect of Acylation of Rapeseed Proteins with Lauroyl and Oleoyl Chloride on Solubility and Film-Forming Properties
}

\author{
Andreas Fetzer $^{1,2} \cdot$ Cornelia Hintermayr $^{2} \cdot$ Markus Schmid $^{3} \cdot$ Andreas Stäbler $^{2} \cdot$ Peter Eisner $^{1,2}$
}

Received: 16 October 2019 / Accepted: 7 March 2020 / Published online: 21 March 2020

(c) The Author(s) 2020

\begin{abstract}
Rapeseed proteins show good film-forming properties, giving them a promising potential as bio-based ingredients for the technical industry, e. g. for films and coatings. However, their hydrophilicity often poses problems in regard to water-stability of coatings. Protein modification using fatty acids is known to reduce hydrophilicity, however, it has not been tested to improve film-forming properties of rapeseed proteins before. In the present study, a rapeseed protein concentrate (RPC) was acylated at low and high modification degree using lauroyl chloride and oleyol chloride. The protein solubility was determined and the modified RPCs were used for the preparation of cast-films to measure the changes of mechanical properties (tensile strength, elongation at break), surface energy, oxygen permeability and light transmission. The protein solubility in water was lowered from $100 \%$ for the non-modified RPC to $<15 \%$ for highly modified RPCs at $\mathrm{pH} 7$. The tensile strength of films increased by factors of 3.5 and 4 for highly modified samples, respectively. Surface energy and oxygen permeability revealed an increase of hydrophobicity that correlated with the modification degree. The light transmission was reduced by modification. The results confirm the increased hydrophobicity of acylated RPCs and demonstrate the potential of modified rapeseed proteins as an ingredient for technical products, such as packaging layers, coatings and adhesives.
\end{abstract}

\section{Graphic Abstract}

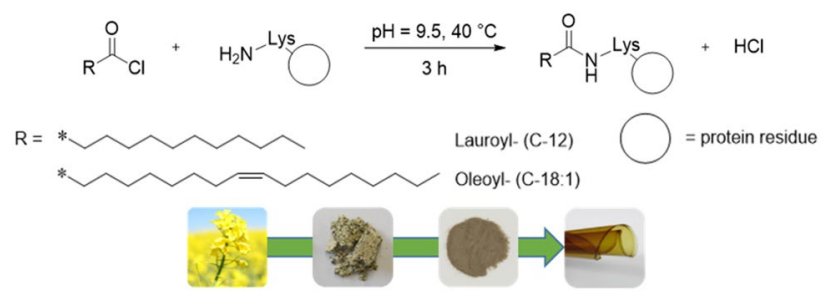

Keywords Rapeseed · Canola Protein modification · Acylation · Film-forming properties · Coating

Andreas Fetzer

andreas.fetzer@ivv.fraunhofer.de

Markus Schmid

schmid@hs-albsig.de

1 Technical University of Munich (TUM), TUM School of Life Sciences Weihenstephan, Alte Akademie 8, 85354 Freising, Germany

2 Fraunhofer Institute for Process Engineering and Packaging IVV, Giggenhauser Str. 35, 85354 Freising, Germany

3 Faculty of Life Sciences, Albstadt-Sigmaringen University, Anton-Günther-Str. 51, 72488 Sigmaringen, Germany

\section{Statement of Novelty}

Rapeseed proteins can be isolated from side-stream products of the rapeseed oil industry and could potentially be valorized as bio-based additives in the technical industry. Despite their great functional properties, rapeseed proteins are not well studied for utilization in the non-food industry. In the present study, acylation of rapeseed proteins was carried out in order to increase their hydrophobicity. This is the first time acylation of rapeseed proteins with long hydrocarbon chains was carried out with the aim to enhance the film-forming properties, which are of high relevance to a 
range of technical applications, such as adhesives, coatings or polymers. The results clearly demonstrate the increase of hydrophobicity, thereby improving the application potential of rapeseed proteins as a renewable alternative to conventional additives.

\section{Introduction}

Plant proteins from oilseed by-products are a promising alternative for petrol-based ingredients in technical applications. In particular, rapeseed proteins with their great functionalities such as foaming, emulsification and filmforming properties are an interesting functional ingredient, e.g. for paints, varnishes, glues and lubricants. Specifically, film-forming properties are of high relevance for such applications. However, as these products are often based on hydrophobic media, the polar nature of proteins can be problematic in regard to product formulation or water-stability [1]. Hence, methods to render rapeseed proteins more hydrophobic and thus to stabilize these formulations are needed.

Application of proteins in detergents, paints, glues and polymers is gaining increasing interest in the proclaimed bio-economy of the twenty-first century. Historically, proteins-predominantly from animal sources-have been an important raw material for adhesives, fire extinguishing foams or plastics $[2,3]$. However, with the advent of the petroleum era, most of these products have been replaced by easier and cheaper methods to produce synthetic materials.

The main storage proteins in rapeseed are the $12 \mathrm{~S}$ globulin cruciferin and the 1.7-2S albumin napin [4]. Due to their flexible structure comprising polar and non-polar residues, they are able to attach on interfaces, such as air/water or oil/ water interfaces, to form and stabilize foams and emulsions [5]. Additionally, great film-forming properties of rapeseed proteins were demonstrated [6-8]. However, methods to increase the hydrophobicity of rapeseed proteins while preserving their functional properties are demanded to enhance the applicability in the non-food sector. A promising technique to achieve this is chemical derivatization of free functional groups in the protein with reagents bearing long hydrocarbon chains [9]. Thereby, polar residues, such as hydroxyl, sulfhydryl or amino groups can be converted to non-polar residues to increase the overall hydrophobicity.

Film-forming properties of rapeseed proteins were described in a number of studies. Several studies describe rapeseed protein-based film-formation by the solvent-cast method, using different protein concentrations, plasticizer types and concentrations $[6,8,10,11]$. Mechanical and barrier properties of these films were reported to be low and comparable to other plant proteins [12]. Some improvements of physical properties were achieved using blends of rapeseed protein and gelidium corneum (a red algae with high agar content) or gelatin [11]. In another study, denaturation by sodium dodecyl sulfate (SDS) prior to film formation also showed some improvement in tensile strength of films [8]. Moreover, the addition of genipin as a natural cross-linker increased tensile strength of sorbitol-plasticized films [10].

Chemical acylation of rapeseed proteins has been reported in a number of previous studies, predominantly in the form of acetylation and succinylation [13-18]. Film properties were investigated only in one study using succinylated rapeseed proteins [13]. The authors reported enhanced barrier and mechanical properties as well as increased hydrophobicity at the lowest modification degree. To the best of the author's knowledge, no study was carried out using rapeseed proteins modified with long hydrocarbon chains for film-preparation.

In this work, we applied the acylation of rapeseed protein preparations by Schotten-Baumann-reaction with fatty acid chlorides (FACs) [19, 20]. Type and degree of modification were investigated and resulting functional properties were compared with the non-modified standard. In particular, the influence on water solubility was studied. Additionally, cast films of rapeseed protein preparations were characterized regarding their mechanical and barrier properties. The overall aim was to show the application potential of rapeseed proteins for technical products requiring film-forming properties such as glues, lubricants, paints and varnishes.

\section{Materials and Methods}

\section{Raw Materials and Chemicals}

Prepressed rapeseed press cake was provided by Bunge Deutschland GmbH, Mannheim, Germany. Rapeseed press cake was defatted with isohexane in a percolator (volume $1.5 \mathrm{~m}^{3}$, e\&e Verfahrenstechnik GmbH, Warendorf, Germany) and flash desolventized with isohexane (400-500 mbar) prior to steam desolventation to obtain defatted rapeseed meal. Isohexane was obtained from Biesterfeld AG (Hamburg, Germany). Lauroyl chloride and olyeol chloride were obtained from Sigma-Aldrich Chemie GmbH (Munich, Germany). Phytase Quantum Blue 5G was obtained from AB Enzymes GmbH (Darmstadt, Germany). All other chemicals were of analytical grade and obtained from Th. Geyer GmbH \& Co. KG (Renningen, Germany), if not stated otherwise.

\section{Preparation of Rapeseed Protein Concentrate}

The RPC was prepared on a pilot scale as follows: Rapeseed meal was added to a $0.25 \mathrm{M}$ aqueous $\mathrm{NaCl}$-solution at $30^{\circ} \mathrm{C}$ with an s:1-ratio of 1:13. The mixture was adjusted to $\mathrm{pH} 9$ using $3 \mathrm{M} \mathrm{NaOH}$ and stirred for $60 \mathrm{~min}$, before separation 
was carried out using a decanter (GEA Westfalia Separator Group $\mathrm{GmbH}$, Oelde, Germany). The supernatant was adjusted to $\mathrm{pH} 4$ with $3 \mathrm{M} \mathrm{HCl}$ at $30{ }^{\circ} \mathrm{C}$ and stirred for 30 min. Separation of the mixture was carried out using a disc separator (GEA Westfalia Separator Group GmbH). The sediment was not of further use in this study. The supernatant was adjusted to pH 5.5 with $3 \mathrm{M} \mathrm{NaOH}$ and $1.1 \mathrm{~g}$ of phytase (Quantum Blue 5G) were added. Ultrafiltration was carried out at $50{ }^{\circ} \mathrm{C}$ on a Microza polysulfone ultrafiltration module SLP-3053 (Pall Corporation, Port Washington, NY, USA) with a molecular weight cutoff of $10 \mathrm{kDa}$ and a membrane area of $4.5 \mathrm{~m}^{2}$. The neutralized retentate was spray-dried at a product inlet temperature of $180^{\circ} \mathrm{C}$ and a product outlet temperature of $75-80^{\circ} \mathrm{C}$ to obtain an RPC with high protein solubility. This was mandatory to ensure proper reactivity during further protein modification.

\section{Modification of RPC}

$100 \mathrm{~g}$ of RPC were dispersed in $900 \mathrm{~g}$ of demineralized water and stirred at $40{ }^{\circ} \mathrm{C}$. The $\mathrm{pH}$ was adjusted to pH 9.5 using $1 \mathrm{M} \mathrm{NaOH}$ and lauroyl chloride or oleoyl chloride ( 15 or $120 \mathrm{mmol}$ ) were added dropwise. The $\mathrm{pH}$ was controlled during addition of fatty acid chloride (FAC) and maintained at $\mathrm{pH} 9.5$. After $3 \mathrm{~h}$, a stable $\mathrm{pH}$ indicated the end-point of the reaction (Fig. 1). The dispersion was cooled to $30{ }^{\circ} \mathrm{C}$, neutralized using $1 \mathrm{M} \mathrm{HCl}$ and dialyzed against demineralized water at $1{ }^{\circ} \mathrm{C}$ for $48 \mathrm{~h}$ with a molecular weight cutoff of $3.5 \mathrm{kDa}$ (Spectra/Por® 3, Spectrum LifeSciences, LLC, Rancho Dominguez, CA, USA). The demineralized water was changed twice a day. The dialyzed samples were lyophilized, homogenized by mortar and pestle and washed six times with ethanol $(3 \mathrm{~mL} / \mathrm{g})$ for removal of non-reacted free fatty acids. After air-drying under a fume hood, the modified RPCs were used for further analysis. A control sample was prepared and treated the same way without the addition of FAC to the protein dispersion. All samples were prepared in duplicate.

\section{Chemical Composition of Rapeseed Samples}

Chemical composition (dry matter, protein) of rapeseed protein samples was analyzed in duplicate. Dry matter was analyzed using a thermo-gravimetrical system (TGA 601, Leco Corporation, St. Joseph, MI, USA) at $105^{\circ} \mathrm{C}$ and $950{ }^{\circ} \mathrm{C}$, respectively. Protein content was measured by Dumas combustion method on a TruMac $\mathrm{N}$ system (Leco Corporation), using 5.7 as the conversion factor [21]. Free fatty acids in the ethanol washing fractions of modified samples were determined by gas chromatography with flame ionization detector (GC-FID) as described by Mahmoud et al. [22].

\section{Properties of Rapeseed Protein Samples}

\section{Protein Solubility}

The protein solubility (PS) was determined in duplicate following the method of Morr et al. [23], as previously described [24]. For each measurement $1.5 \mathrm{~g}$ of rapeseed protein concentrate were suspended in a total volume of $50 \mathrm{~mL}$ of a $0.1 \mathrm{M} \mathrm{NaCl}$ solution. The $\mathrm{pH}$ was adjusted using $0.1 \mathrm{M}$ $\mathrm{NaOH}$ or $0.1 \mathrm{M} \mathrm{HCl}$, respectively. After stirring for $1 \mathrm{~h}$ at room temperature, the samples were centrifuged $(20,000 \times g$, $15 \mathrm{~min}, 15^{\circ} \mathrm{C}$ ) and the supernatant was filtrated (Whatman No. 1 filter paper). Protein content of the supernatant was determined according to Dumas following the method given in section "Analysis of Chemical Composition of Rapeseed Preparations". Protein solubility was calculated using Eq. 1 and reported giving the mean value \pm absolute deviation.

Protein solubility $[\%]=\frac{\text { initial volume }[\mathrm{mL}] \times \text { protein content in supernatant }[\mathrm{mg} / \mathrm{mL}]}{\text { sample mass }[\mathrm{mg}] \times \text { protein content }[\% \mathrm{dm}] \times \operatorname{dry} \text { matter }[\%]} \times 100$

Fig. 1 Reaction scheme for the modification of rapeseed proteins via Schotten-Baumannreaction

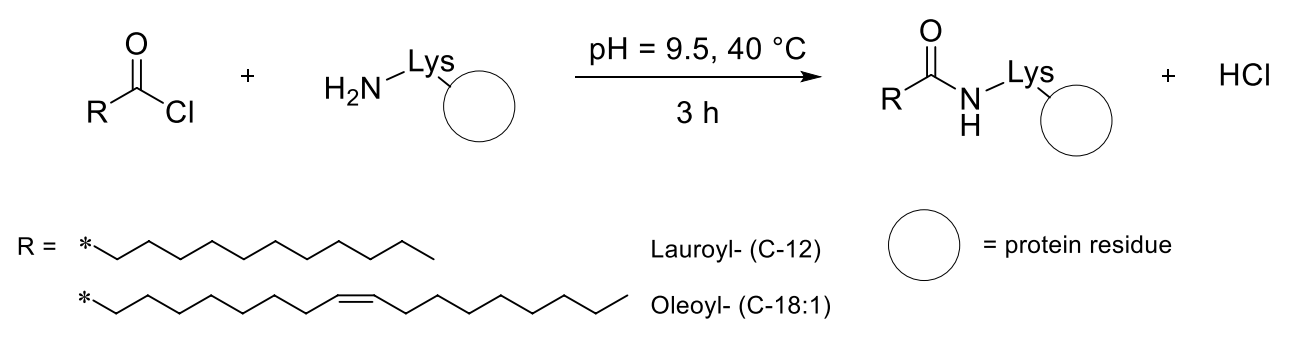




\section{Film-Forming Properties}

\section{Preparation of Cast Films}

Cast films of RPCs were prepared as described by Chang and Nickerson [6] with minor modifications. $11.25 \mathrm{~g}$ of modified or non-modified RPC were mixed with $120 \mathrm{~mL}$ of demineralized water in a glass bottle and the $\mathrm{pH}$ was adjusted to $\mathrm{pH} 3$ using $1 \mathrm{M} \mathrm{HCl}$. The mixture was stirred at room temperature for $60 \mathrm{~min}$ at $300 \mathrm{rpm}$ on a MIX $15 \mathrm{mag}$ netic stirrer (2mag AG, Munich, Germany), before $2.81 \mathrm{~g}$ of glycerol were added. The total weight was adjusted to $150 \mathrm{~g}$ at $\mathrm{pH} 3$ using demineralized water and $1 \mathrm{M} \mathrm{HCl}$ and stirring was continued for $10 \mathrm{~min}$. The mixture was degassed in an ultrasound bath at $35 \mathrm{kHz}$ and $50{ }^{\circ} \mathrm{C}$ for $15 \mathrm{~min}$, stirred at $50{ }^{\circ} \mathrm{C}$ and $300 \mathrm{rpm}$ and $33 \mathrm{~g}$ were cast in square petri dishes $(120 \mathrm{~mm} \times 120 \mathrm{~mm})$. The cast film was dried at $23^{\circ} \mathrm{C}$ and $50 \% \mathrm{RH}$ for 14 days to equilibrium moisture content.

\section{Film Thickness}

The rapeseed protein films were peeled off the petri dishes and the film thickness was determined using a Precision Thickness Gauge (Hanatek Instruments, St. Leonards-onSea, UK) as previously described by Schmid [25]. The measurements were performed at $23{ }^{\circ} \mathrm{C}$ and $50 \% \mathrm{RH}$ with a five-fold determination at five different positions. The arithmetic average of the film thickness was used to calculate standardized oxygen permeability (OP) and mechanical film properties.

\section{Surface Energy}

The surface energy of RPC-based films was measured by the sessile drop method as previously described [25], using the contact angle measuring system G2 (Krüss GmbH, Stephanskirchen/Rosenheim, Germany). The contact angle of three testing liquids (water, diiodomethane, ethylene glycol) was measured at $22.4^{\circ} \mathrm{C}$ and $42 \% \mathrm{RH}$ at five different positions on the film surface of five replicates. The results are given as the arithmetic average \pm standard deviation. According to Young's equation, the surface energy was calculated as follows:

$\sigma_{s}=\gamma_{s l}+\sigma_{l} \times \cos \theta$

where $\sigma_{s}$ is the surface tension of the solid (film) in $\mathrm{mN} / \mathrm{m}$, $\sigma_{l}$ is the surface tension of the liquid in $\mathrm{mN} / \mathrm{m}, \gamma_{s l}$ is the interfacial tension between the solid and the liquid in $\mathrm{mN} / \mathrm{m}$ and $\cos \theta$ is the contact angle between the surface tension of the liquid and the interfacial tension between the liquid and solid in angular degree. The disperse and polar fractions of the surface energy were calculated according to the method by Owens et al. [26-28]. As the rapeseed films were watersoluble, the measurement had to be performed directly after drop application rather than at equilibrium. The calculated values can thus not be classified as absolute surface energy values and are only used for comparison of the samples in this study.

\section{Tensile Testing}

Tensile properties of RPC films were measured on a universal compression-tension testing machine Zwick 1445 (ZwickRoell GmbH \& Co. KG, Ulm, Germany) at $23^{\circ} \mathrm{C}$ and $50 \% \mathrm{RH}$ in accordance to the standard DIN 527-1. The cast films were cut into strips $(15 \mathrm{~mm} \times 70 \mathrm{~mm})$ and the thicknesses of the film strips were measured. The film strip was clamped in the loading frame using pneumatic grips and an initial gauge length of $50 \mathrm{~mm}$. The sample was subjected to an applied force using a load cell of $50 \mathrm{~N}$ and was stretched with a testing speed of $100 \mathrm{~mm} / \mathrm{min}$. For each sample, a fivefold determination was performed and the tensile strength (TS; MPa) and elongation at break (\%) were reported as the arithmetic average \pm standard deviation.

\section{Oxygen Permeability}

The oxygen permeability (OP) was measured according to the standard DIN 53380-3 at $23{ }^{\circ} \mathrm{C}$ and $50 \%$ RH on a Mocon Twin instrument (Mocon Inc., Minneapolis, USA) as previously described $[25,29]$. The OP values $(Q)$ were converted to a thickness $(d)$ of $100 \mu \mathrm{m}\left(Q_{100}\right)$, according to Eq. 3, and are given in the unit $\left[\mathrm{cm}^{3} \mathrm{~m}^{-2} \mathrm{~d}^{-1}\right.$ bar $\left.^{-1}\right]$.

$Q_{100}=Q \times \frac{d}{100}$

\section{Light Transmission}

Light transmission of rapeseed protein films was measured with a spectrophotometer TMQ (Carl Zeiss GmbH, Oberkochen, Germany) in duplicate at wavelengths of $350 \mathrm{~nm}, 430 \mathrm{~nm}, 450-750 \mathrm{~nm}$ (intervals of $25 \mathrm{~nm}$ ), and $800-1000 \mathrm{~nm}$ (intervals of $50 \mathrm{~nm}$ ).

\section{Degree of Modification Using the o-Phtaldialdehyde Method}

Calculation of the degree of modification (DM) was performed via determination of free $\alpha$-amino groups with $o$-phtaldialdehyde (OPA) according to Nielsen et al. using $N, N$-dimethyl-2-mercaptoethylammonium chloride as the thiol component $[30,31]$. Protein samples were analyzed in 
triplicate using serine as a standard. Initially, the degree of hydrolysis (DH) was calculated using the Eqs. 4-6.

$D H=\frac{h}{h_{\text {tot }}} \times 100 \%$

where $h_{\text {tot }}$ is the total number of peptide bonds per protein equivalent (adopted from soy protein with $\mathrm{h}_{\text {tot }}=7.8$ according to Adler-Nissen [32]) and $h$ is the number of hydrolyzed bonds.

$h=\frac{\text { Serine }-\mathrm{NH}_{2}-\beta}{\alpha} \frac{\text { meqv }}{g_{\text {Protein }}}$

where Serine- $\mathrm{NH}_{2}=$ meqv serine- $\mathrm{NH}_{2} / \mathrm{g}_{\text {protein }}, \alpha=0.970$ and $\beta=0.342$ (constants adopted from soy protein according to Adler-Nissen [32]).

Serine $-\mathrm{NH}_{2}=\frac{O D_{\text {sample }}-O D_{\text {blank }}}{O D_{\text {standard }}-O D_{\text {blank }}} \times 0.9516 \frac{m e q v}{L} \times \frac{0.1 L \times 100}{X g \times P}$

where $0.1 \mathrm{~L}$ is the sample volume, $\mathrm{X}$ is the sample mass (in grams) and $\mathrm{P}$ is the protein content of the sample (in percent).

The DM was calculated from the DH using Eqs. 7 and 8.

Percentage of free amino groups $=\frac{D H_{\text {modified } R P C}}{D H_{R P C}} \times 100 \%$

where $\mathrm{DH}_{\text {modified RPC }}$ is the $\mathrm{DH}$ of the RPC after modification and $\mathrm{DH}_{\mathrm{RPC}}$ is the $\mathrm{DH}$ of the RPC.

$D M=100 \%-$ percentage of free amino groups

Due to the inaccuracy of the method at low DH [30], no absolute values were used for the comparison of modified RPCs. Instead, the relative degree of modification (RDM) was used, which was calculated in relation to the sample with the highest DM (RPC-LH) according to Eq. 9:

$R D M=\frac{D M_{\text {modified } R P C}}{D M_{R P C-L H}} \times 100 \%$

\section{Statistical Analysis}

All data are given as mean values \pm standard deviation of at least two measurements $(n=2)$. Outliers were eliminated after applying Grubb's test and the data was tested for normal distribution according to Shapiro-Wilk. Significant differences were statistically analyzed by one-way analysis of variance using Tukey's test $(p<0.05)$. Statistical analysis was performed using the software OriginPro (OriginLab Corporation, Northampton, USA).

\section{Results and Discussion}

\section{Modification of Rapeseed Protein Concentrate}

The RPC was chemically modified by the Schotten-Baumann-reaction using lauroyl chloride (LC) and oleoyl chloride (OC). A screening showed the relative degree of modification (RDM) in dependence of the amount of fatty acid chloride (FAC) used (Fig. 2). As expected, the RDM increased with increasing amounts of FAC. The RDM was in the range of $41.0-86.6 \%$ and $39.5-70.4 \%$ for LC and OC, respectively. Higher RDMs for lauroyl-modified samples were possibly due to lower sterical hindrance for the reaction with the protein residues, due to the smaller and less bulky chemical structure of LC in comparison to OC.

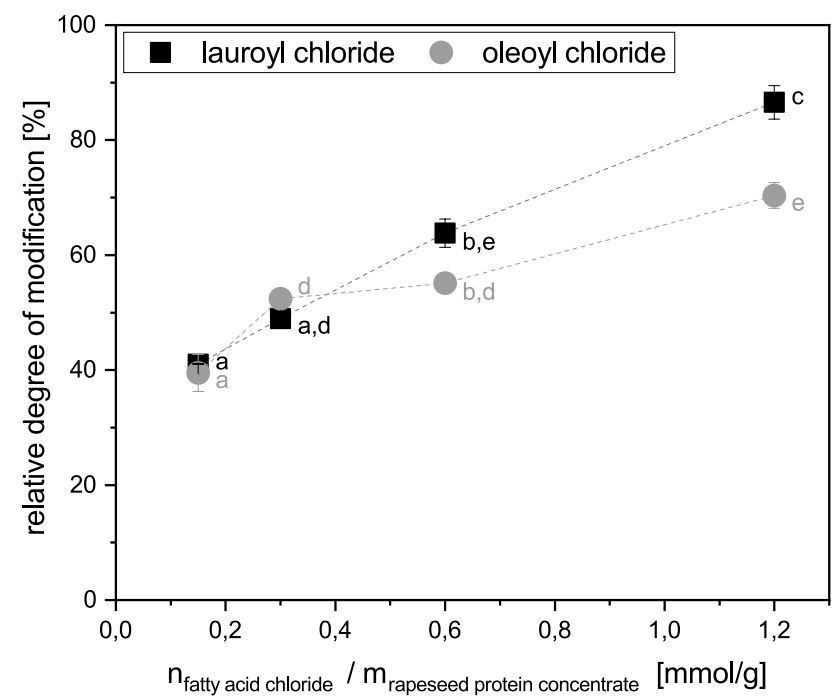

Fig. 2 Screening for the degree of modification in dependence of the amount of fatty acid chloride (FAC) used in the reaction (mean values \pm absolute deviation); data points having the same superscript indicate no significant difference $(p>0.05)$

Table 1 Relative degree of modification and composition of rapeseed protein concentrates (mean values \pm absolute deviation): $L L$ LauricLow, $L H$ Lauric-High, $O L$ Oleic-Low, $O H$ Oleic-High; protein contents were calculated with a nitrogen-to-protein conversion factor of 5.7; values within one row having the same superscript indicate no significant difference $(p>0.05)$

\begin{tabular}{lcll}
\hline & $\begin{array}{l}\text { Relative degree of } \\
\text { modification (RDM) } \\
(\%)\end{array}$ & $\begin{array}{l}\text { Dry matter }(\mathrm{dm}) \\
(\%)\end{array}$ & $\begin{array}{l}\text { Protein content } \\
(\% \mathrm{dm})\end{array}$ \\
\hline RPC & - & $94.9 \pm 0.0^{\mathrm{a}}$ & $83.7 \pm 0.1^{\mathrm{a}}$ \\
RPC-LL & $32.6 \pm 0.2^{\mathrm{a}}$ & $94.4 \pm 0.1^{\mathrm{a}}$ & $83.5 \pm 0.1^{\mathrm{a}}$ \\
RPC-LH & $100.0 \pm 3.2^{\mathrm{b}}$ & $95.3 \pm 0.0^{\mathrm{a}}$ & $76.7 \pm 0.5^{\mathrm{b}}$ \\
RPC-OL & $27.8 \pm 2.6^{\mathrm{a}}$ & $94.4 \pm 0.0^{\mathrm{a}}$ & $82.7 \pm 0.4^{\mathrm{a}}$ \\
RPC-OH & $72.3 \pm 1.3^{\mathrm{c}}$ & $94.6 \pm 0.4^{\mathrm{a}}$ & $77.1 \pm 0.0^{\mathrm{b}}$ \\
\hline
\end{tabular}




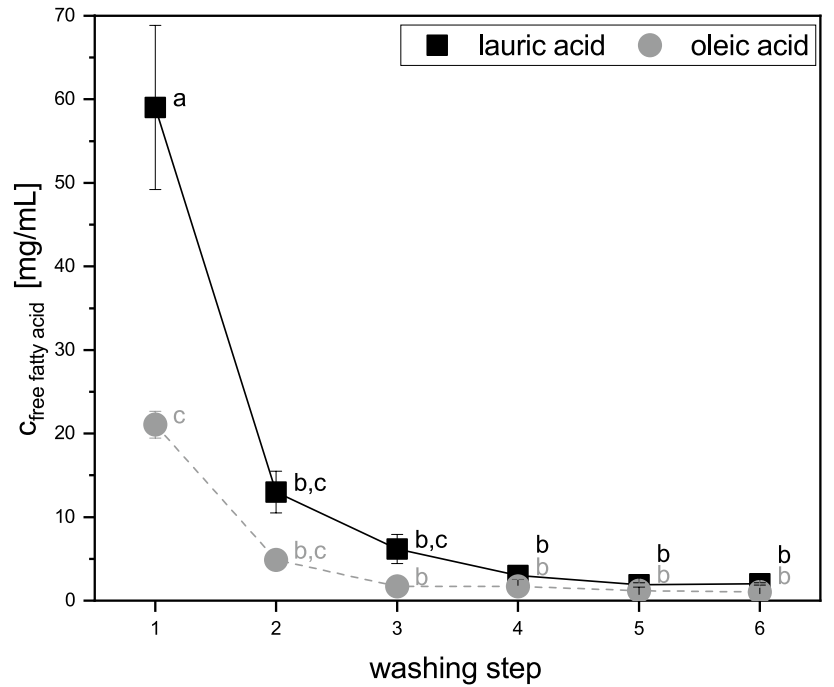

Fig. 3 Concentration of free fatty acids in the ethanol washing fractions (mean values \pm absolute deviation); data points having the same superscript indicate no significant difference $(p>0.05)$

Based upon the screening, the amount of FAC added to the reaction was chosen to yield one low-modified and one high-modified RPC for lauroyl and oleoyl chloride. Accordingly, an up-scale of the reaction was carried out using 0.15 and $1.2 \mathrm{mmol}_{\mathrm{FAC}} / \mathrm{g}_{\mathrm{RPC}}$. The RDM for the low-modified species was determined to be $32.6 \%$ and $27.8 \%$ for $\mathrm{LC}$ and OC, respectively (Table 1). Lower RDMs compared to the screening could be explained by a higher degree of FAC that was hydrolyzed in the aqueous mixture due to a lower initial concentration upon dropwise addition of the reagent. In case of the high-modified species, the RDM of $72.3 \%$ was comparable to the screening for OC. However, for LC the RDM (100.0\%) was higher compared to the screening.

To remove free fatty acids from the reaction product, dialysis of the reaction mixture was followed by ethanol washing of the lyophilized samples. The content of fatty acids in the washing fractions was analyzed for the high-modified samples RPC-LH and RPC-OH (Fig. 3). The concentration of fatty acids in the first fraction was $59.0 \mathrm{mg} / \mathrm{mL}$ and $21.1 \mathrm{mg} /$ $\mathrm{mL}$ and dropped to $2.0 \mathrm{mg} / \mathrm{mL}$ and $1.0 \mathrm{mg} / \mathrm{mL}$ in the final fraction for RPC-LH and RPC-OH, respectively. In total, six washing steps were carried out for the purification of the modified RPCs. Statistical analysis revealed no significant differences in the concentration of free fatty acids after the third washing step $(p>0.05)$.

\section{Characterization of Rapeseed Protein Concentrates}

\section{Chemical Composition}

The chemical composition was determined for the non-modified and all modified RPCs (Table 1). The protein content of

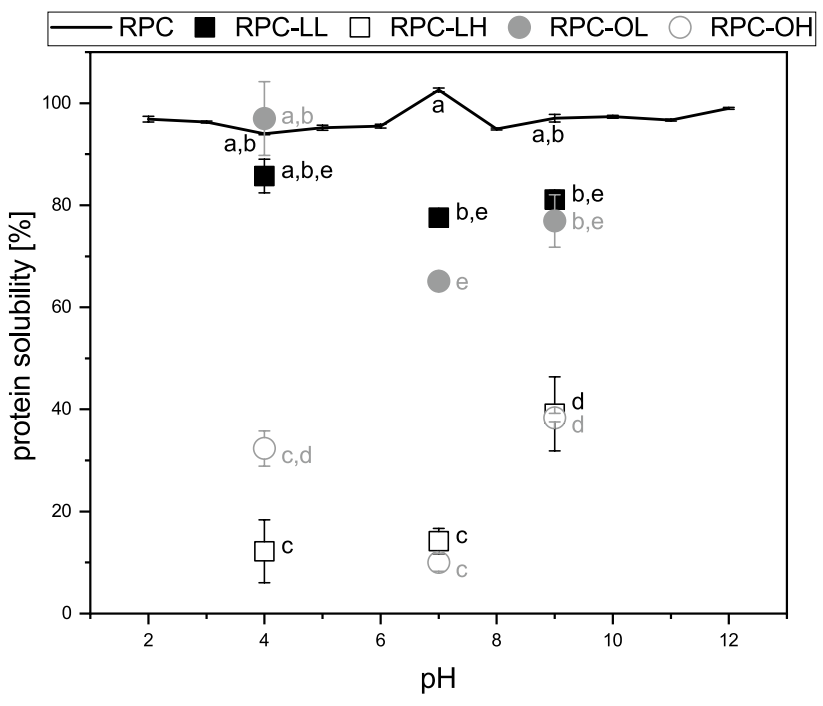

Fig. 4 Protein solubility in $0.1 \mathrm{M} \mathrm{NaCl}$ of rapeseed protein concentrates (mean values \pm absolute deviation); data points having the same superscript indicate no significant difference $(p>0.05)$

the non-modified RPC was $83.7 \% \mathrm{dm}(\mathrm{N} \times 5.7)$. As expected, the protein content determined using the same conversion factor was reduced with increasing modification degree. The protein content was reduced marginally $(0.2-1.0$ percentage points) for the low-modified species RPC-Lauric-Low (-LL) and RPC-Oleic-Low (-OL). For the high-modified species, the protein content dropped to $76.7 \%$ and $77.1 \%$ for RPCLauric-High (-LH) and RPC-Oleic-High (-OH), respectively.

\section{Properties of Rapeseed Protein Concentrates}

Protein Solubility To obtain good reactivity during the reaction, an RPC with good water solubility was chosen. The protein solubility of the RPC was $>90 \%$ in the range of $\mathrm{pH} 2-12$ (Fig. 4), which was achieved by removal of the low-soluble protein fraction by a preceding precipitation step. For the modified RPCs the solubility was determined at $\mathrm{pH} 4,7$ and 9 to analyze the effects of acylation on water solubility in acidic, neutral and alkaline environment. The solubility was reduced for all modified RPCs with one exception. The effect was less pronounced for the lowmodified species RPC-LL and RPC-OL, with reductions of $8-25 \%$ points and $0-37 \%$ points, respectively. For RPC-LH and RPC-OH, the protein solubility dropped to $12.2-39.1 \%$ and $10.0-38.4 \%$, respectively. Reduction of solubility can be explained by fatty acid amidation of free amino groups (primarily the $\varepsilon$-amino group of exposed lysyl residues), and to some degree of free hydroxyl and sulfhydryl groups. Water solubility is reduced, as these groups are limited in the ability to form hydrogen bonds in aqueous environment after acylation. Additionally, refolding of the protein structure has to be considered, which can lead to the liberation 
Fig. 5 Photographs of rapeseed protein films after drying and removal of the petri dish
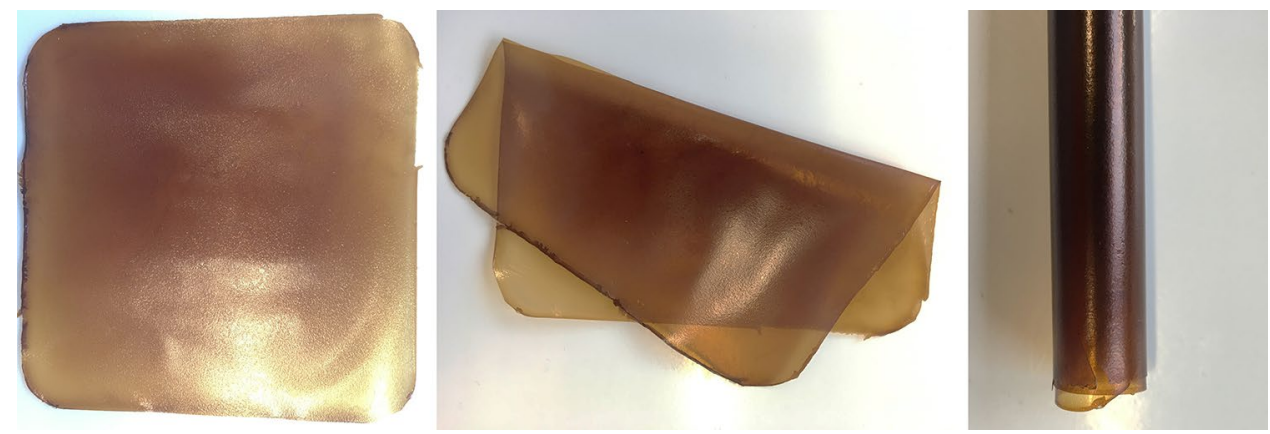

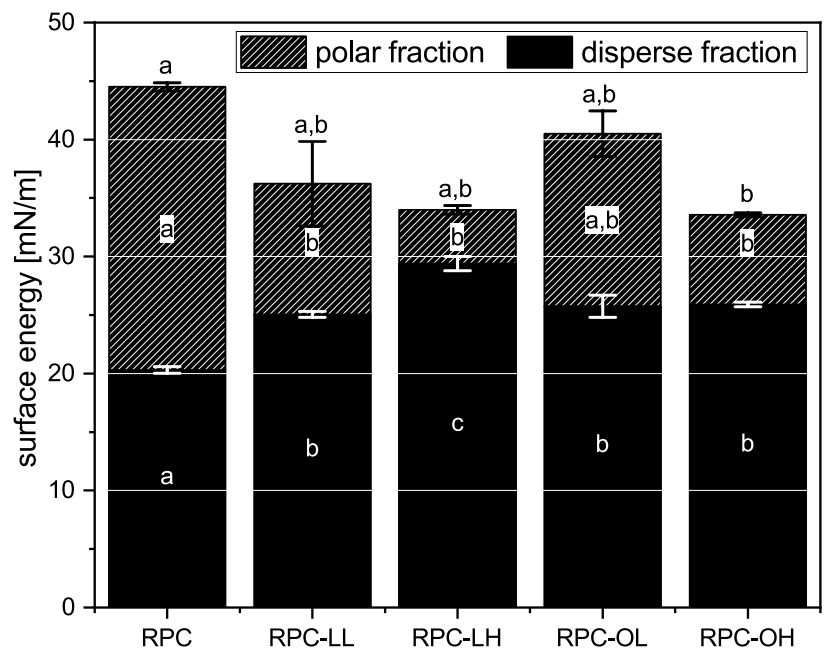

Fig. 6 Surface energy of cast-films made from rapeseed protein concentrates (mean values \pm absolute deviation); columns having the same superscript indicate no significant difference $(p>0.05)$; significance indexes are given for disperse fraction, polar fraction and surface energy separately

of buried hydrophobic amino acid residues. For the lowmodified samples, the protein solubility was reduced only to a limited extent, with significant differences only at $\mathrm{pH} 7$ $(p<0.05)$. However, the solubility was greatly reduced for high-modified samples. The solubility reduction was most pronounced at $\mathrm{pH}$ 7. This might be explained by a shift of the isoelectric point from the alkaline into the neutral region upon amidation of basic lysyl groups.

\section{Properties of Rapeseed Protein Concentrate Films}

All RPCs showed good film-forming properties in cast-film experiments using glycerol as a plasticizer $(25 \%$ on the RPC sample basis). After removal of the dried film from the petridish, all films appeared homogenous, without defects, flexible, and were of brown color. The appearance as well as foldability and rollability of films is displayed in Fig. 5.
Surface Properties Measurement of the surface energy showed the increased hydrophobicity of films prepared from acylated RPCs (Fig. 6). Films from the unmodified RPC showed a surface energy of $44.5 \mathrm{mN} / \mathrm{m}$, with a polar fraction of $24.2 \mathrm{mN} / \mathrm{m}$. For the modified RPCs, the surface energy decreased with increasing modification degree. This was caused by a decrease of the polar fraction, which was higher than the increase of the disperse fraction. The surface energy decreased to $36.2 \mathrm{mN} / \mathrm{m}$ (LL) and $34.0 \mathrm{mN} / \mathrm{m}$ (LH) for lauroyl-modifications and to $40.5 \mathrm{mN} / \mathrm{m}(\mathrm{OL})$ and $33.6 \mathrm{mN} / \mathrm{m}(\mathrm{OH})$ for oleoyl-modifications. The findings and the increase of disperse interactions caused by the introduction of hydrophobic side chains into the protein.

Barrier Properties All films (non-modified and modified) showed a low water-stability and thus water vapor permeability (WVP) could not be measured. WVP values were reported previously for cast films of rapeseed proteins prepared by a similar method as the one used in this study [6, 10]. This indicates that the nature of the rapeseed protein sample may be crucial for the resulting water stability of the obtained film. High water solubility of rapeseed protein films suggests possible applications such as a water-soluble packaging for dish-washer tabs. For the application as a packaging material or coating, improvement of water resistance must be achieved, e. g. by means of protein denaturation, such as through temperature treatment, or the inclusion of hydrophobic materials in the film. However, the introduction of lauroyl or oleoyl side chains in this study did not sufficiently improve the water stability of the films.

The oxygen permeability (OP) increased with increasing modification degree of the samples (Fig. 7), demonstrating the increase in hydrophobicity within the protein film layer, as oxygen is a nonpolar molecule. In addition, the covalently bound acyl residues can act as an internal plasticizer [33], thereby increasing gas diffusivity. For low-modified RPCs, the OP increased only marginally by $9-26 \%$ without significance $(p>0.05)$. The effect was greatly higher with significance $(p<0.05)$ for high-modified samples, with an increase of the OP by $143-159 \%$. No studies were found reporting OP values for films made from rapeseed proteins such that 


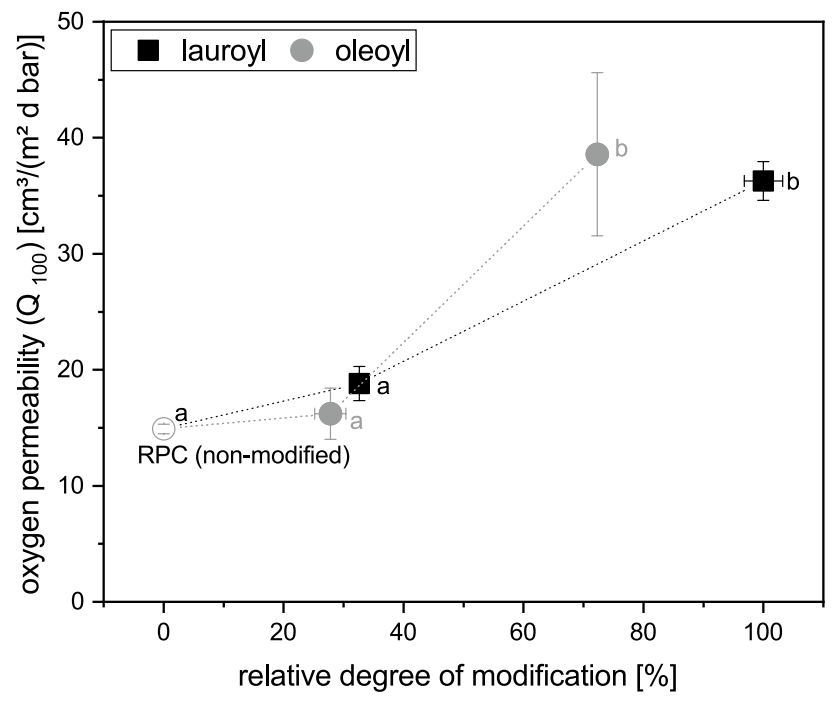

Fig. 7 Oxygen permeability $\left(Q_{100}\right)$ at $23{ }^{\circ} \mathrm{C}$ and $50 \% \mathrm{RH}$ of films prepared from modified and non-modified rapeseed protein concentrates (mean values \pm absolute deviation); data points having the same superscript indicate no significant difference $(p>0.05)$

a comparison was not possible. However, the OP obtained for the non-modified RPC and low-modified RPCs was comparable for the value of $18.4 \mathrm{~cm}^{3} \mathrm{~m}^{-2} \mathrm{~d}^{-1}$ bar $^{-1}$ reported by Schmid et al. [34] for a whey protein based cast film.

Mechanical Properties Compared to other studies using rapeseed proteins, the tensile strength (TS) for films prepared from unmodified RPC was low with $0.6 \mathrm{MPa}$ (Fig. 8). Modification of the RPC showed an increase of the TS with increasing modification degree, presumably due to an increase in non-polar interactions (van der Waals forces) within the film matrix. Low-modified samples showed values of 1.3 MPa (lauroyl) and 1.2 MPa (oleoyl). The TS of high-modified samples increased to $2.4 \mathrm{MPa}$ (lauroyl) and 1.7 $\mathrm{MPa}$ (oleoyl). In accordance, the elongation at break was reduced with increasing degree of modification from $151 \%$ (non-modified RPC) to $104 \% / 121 \%$ and $9.5 \% / 43.3 \%$ for RPC-LL/-OL and RPC-LH/-OH, respectively (Fig. 8).

The modification of RPC showed an increase in the TS, however, all values determined were low in comparison to literature studies. Chang and Nickerson [6] reported a TS of 6.6 MPa for cast-films prepared with a similar method as in the present study using $7.5 \%$ rapeseed protein sample (based on the sample mass) and $30 \%$ glycerol. In a previous study by the authors, formulations of $5 \%$ protein and $50 \%$ glycerol, sorbitol or PEG-400 as a plasticizer were tested [10]. While glycerol showed the lowest TS (1.2 MPa), improvements were achieved using PEG-400 (5.2 MPa) or sorbitol (10.0 MPa) as a plasticizer. With the addition of genipin as a cross-linker, TS values increased to $2.6 \mathrm{MPa}$ (glycerol), 9.6 MPa (PEG-400) and 12.6 MPa (sorbitol). Using a casting process at $\mathrm{pH} 11$ and $70{ }^{\circ} \mathrm{C}$, Shi and Dumont [8] measured a TS of 0.7-1.7 MPa for films prepared from 5\% protein sample and 25-40\% glycerol. Denaturation with SDS (5-15\%) prior to film formation increased TS to 2.3-3.8 $\mathrm{MPa}$, while the use of stearic acid (5-15\%) had a lesser effect (1.5-2.2 MPa). In another study, the TS of non-modified rapeseed protein was $\sim 5.3 \mathrm{MPa}$ for films prepared using $2.6 \%$ protein sample and $42.5 \%$ glycerol by solvent-casting followed by heat-compression [35].

The studies listed above demonstrate the various methods available to increase the TS of protein films. While the effect
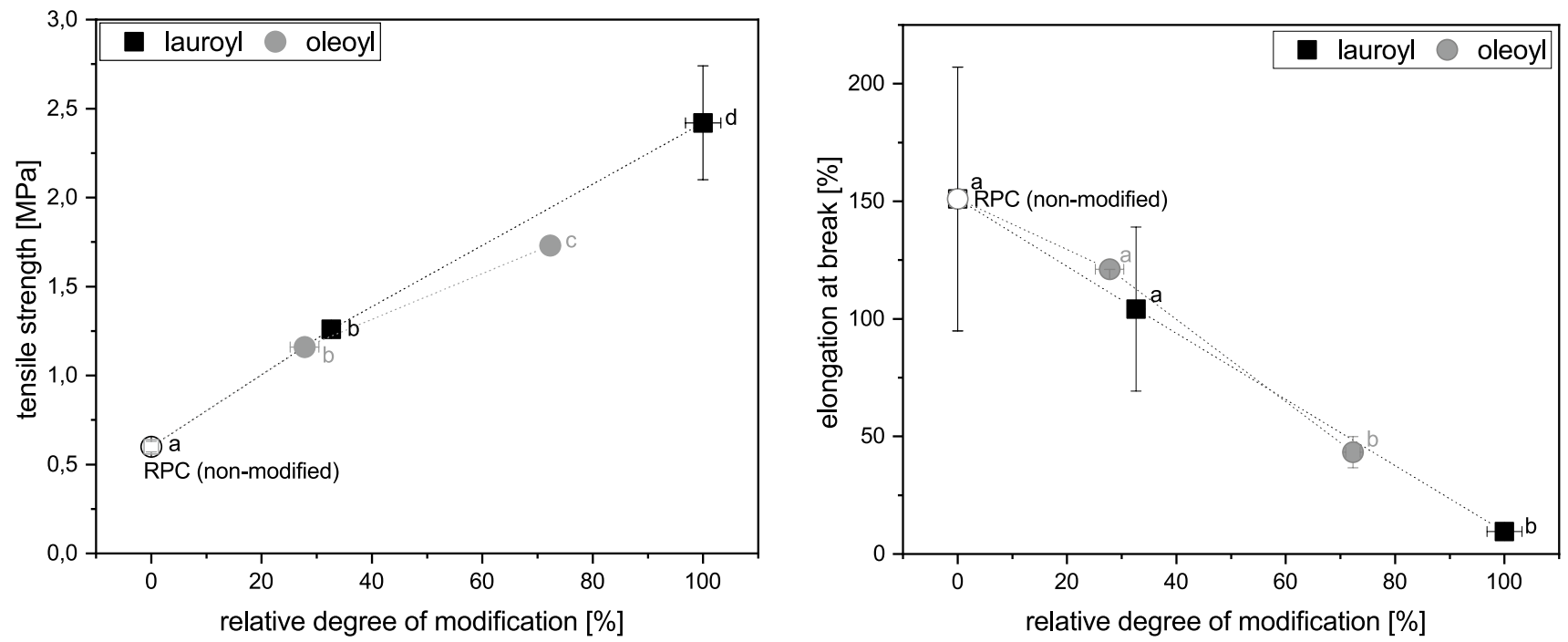

Fig. 8 Tensile strength and elongation at break of films prepared from rapeseed protein concentrates (mean values \pm absolute deviation); data points having the same superscript indicate no significant difference $(p>0.05)$ 


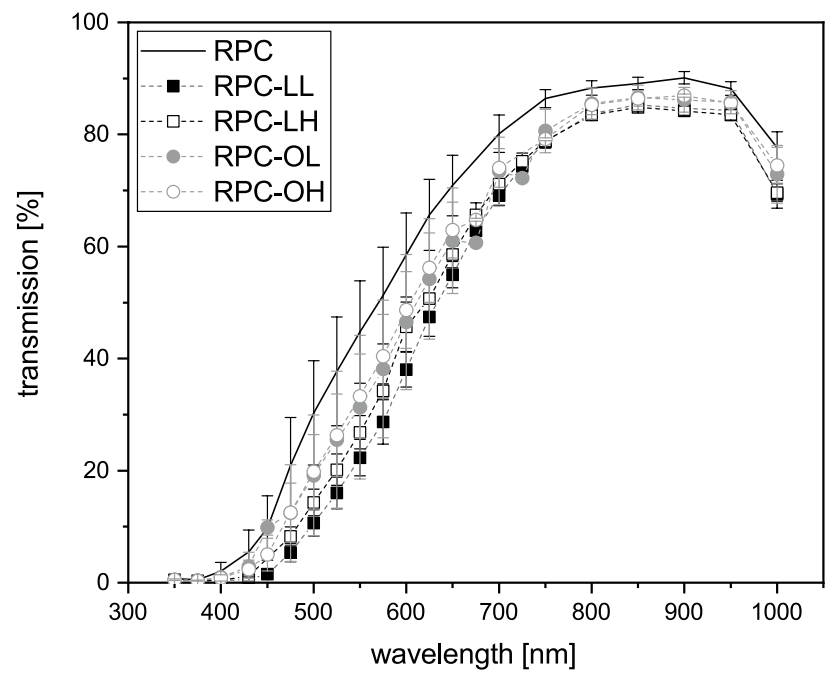

Fig. 9 Light transmission of films prepared from rapeseed protein concentrates in the range of $350-1000 \mathrm{~nm}$ (mean values \pm absolute deviation)

of protein acylation prior to film formation applied in the present study showed only limited effect, a combination of methods, such as chemical modification and heat treatment, may be the subject of further studies.

Light Transmission All films were of brown color and showed only limited transparency. Light transmission was measured at wavelengths of 350-1000 nm. All films showed a transmittance of $<10 \%$ below $450 \mathrm{~nm}$ and very low transmittance of $\leq 2 \%$ in the range of 350-400 nm (Fig. 9). Modification of the RPC reduced the light transmittance of the prepared films. The effect was stronger for lauroyl modifications as compared to oleoyl modifications. The RDM also had a minor effect such that, interestingly, films with lower modification degree showed slightly lower transmittance. The introduction of lipids into protein films has been related to increased opacity in a number of studies [36-40]. In one study, the fatty acid saturation degree correlated with opacity, indicating that saturated stearic acid increased opacity, whereas the effect of oleic acid and linoleic acid was only marginal [40]. The observation may be explained by a lower melting temperature of oleic and linoleic acid compared to stearic acid. Similarly, Jiménez et al. [41] studied the opacity of hydroxypropyl-methylcellulose films formulated with various fatty acids. Saturated fatty acids showed an increased ability to form lipid aggregates, which was thought to be the reason for higher opacity.

The low light transmittance of rapeseed protein films in general, and of films from modified RPCs in particular, suggests the utilization as a packaging material with good light protection. However, as the films were highly watersoluble and showed low barrier properties against oxygen in this study, the rapeseed protein film needs to be used in combination with other materials, e. g. in a multi-layered material. Alternatively, the natural color of the obtained rapeseed protein films might serve well in an application such as a coating for cardboard or wood.

\section{Conclusions}

The reduction of hydrophilicity of rapeseed protein concentrates was successfully achieved by acylation with lauroyl and oleoyl chloride. The protein solubility in water at neutral $\mathrm{pH}$ was reduced from $100 \%$ to $<15 \%$ for highly modified samples. Contact angle measurement revealed the increased hydrophobicity of cast films from modified RPCs, however, the films still showed low water stability. The observed properties may serve well for the production of water-soluble foils, such as for dish-washer tabs. Films from modified protein samples showed an increase in tensile strength with increasing modification degree, while the elongation at break was reduced consequently. The light transmission of all films was $<10 \%$ below $450 \mathrm{~nm}$ and was further reduced by modification, suggesting a potential application as a light-protecting packaging layer. In summary, the application potential of rapeseed proteins — both modified and non-modified-as bio-based and biodegradable ingredients with great filmforming properties was demonstrated. Based on the results, suggested application fields are adhesives, coatings, paints, packaging layers, or detergents. Further studies need to be performed to test their applicability in more detail.

Acknowledgements Open Access funding provided by Projekt DEAL. The authors would like to thank the German Federal Ministry of Education and Research (Grant Number: 031A363C) for funding this work. Rapeseed raw materials used in this work were received by Bunge Deutschland GmbH. The authors are thankful to Michael Frankl, Michael Schott and Klaus Schreiber for assisting in the preparation of the rapeseed protein concentrate and to Elfriede Bischof, Sigrid Gruppe, Eva Müller, and Veronika Wildgruber for the assistance in analytical work.

\section{Compliance with Ethical Standards}

Conflict of interest All authors declare that they have no conflict of interest.

Open Access This article is licensed under a Creative Commons Attribution 4.0 International License, which permits use, sharing, adaptation, distribution and reproduction in any medium or format, as long as you give appropriate credit to the original author(s) and the source, provide a link to the Creative Commons licence, and indicate if changes were made. The images or other third party material in this article are included in the article's Creative Commons licence, unless indicated otherwise in a credit line to the material. If material is not included in the article's Creative Commons licence and your intended use is not permitted by statutory regulation or exceeds the permitted use, you will need to obtain permission directly from the copyright holder. To view a copy of this licence, visit http://creativecommons.org/licenses/by/4.0/. 


\section{References}

1. Zhang, Y., Liu, Q., Rempel, C.: Processing and characteristics of canola protein-based biodegradable packaging: a review. Crit. Rev. Food Sci. Nutr. 58(3), 475-485 (2018). https://doi. org/10.1080/10408398.2016.1193463

2. Ralston, B.E., Osswald, T.A.: The history of tomorrow's materials: protein-based biopolymers. Plast. Eng. 64(2), 36-40 (2008). https://doi.org/10.1002/j.1941-9635.2008.tb00292.x

3. Ratzer, A.F.: Method of making fire extinguishing foam. US2361057A,

4. Wanasundara, J.P.D.: Proteins of brassicaceae oilseeds and their potential as a plant protein source. Crit. Rev. Food Sci. Nutr. 51(7), 635-677 (2011). https://doi.org/10.1080/104083910037499 42

5. Magdassi, S., Kamyshny, A.: Introduction: surface activity and functional properties of proteins. In: Magdassi, S. (ed.) Surface Activity of Proteins: Chemical and Physicochemical Modifications. Marcel Dekker, Inc., New York (1996)

6. Chang, C., Nickerson, M.T.: Effect of protein and glycerol concentration on the mechanical, optical, and water vapor barrier properties of canola protein isolate-based edible films. Food Sci. Technol. Int. 21(1), 33-44 (2015). https://doi.org/10.1177/10820 13213503645

7. Manamperi, W.A., Espinoza-Perez, J.D., Haagenson, D.M., Ulven, C.A., Wiesenborn, D.P., Pryor, S.W.: Influence of oil extraction method on properties of canola biodiesel, epoxies, and proteinbased plastics. Ind. Crops Prod. 77(Supplement C), 133-138 (2015). https://doi.org/10.1016/j.indcrop.2015.08.050

8. Shi, W., Dumont, M.-J.: Processing and physical properties of canola protein isolate-based films. Ind. Crops Prod. 52, 269-277 (2014). https://doi.org/10.1016/j.indcrop.2013.10.037

9. Zink, J., Wyrobnik, T., Prinz, T., Schmid, M.: Physical, chemical and biochemical modifications of protein-based films and coatings: an extensive review. Int. J. Mol. Sci. 17(9), 1376 (2016)

10. Chang, C., Nickerson, M.T.: Effect of plasticizer-type and genipin on the mechanical, optical, and water vapor barrier properties of canola protein isolate-based edible films. Eur. Food Res. Technol. 238(1), 35-46 (2014). https://doi.org/10.1007/s00217-013-2075-x

11. Jang, S.A., Lim, G.O., Bin Song, K.: Preparation and mechanical properties of edible rapeseed protein films. J. Food Sci. 76(2), C218 C223 (2011). https://doi.org/10.1111/j.1750-3841.2010.02026.x

12. Shi, W., Dumont, M.J.: Review: bio-based films from zein, keratin, pea, and rapeseed protein feedstocks. J. Mater. Sci. 49(5), 19151930 (2014). https://doi.org/10.1007/s10853-013-7933-1

13. He, R., Dai, C.X., Li, Y., Wang, Z.G., Li, Q., Zhang, C., Ju, X.R., Yuan, J.: Effects of succinylation on the physicochemical properties and structural characteristics of edible rapeseed protein isolate films. J. Am. Oil Chem. Soc. 96(10), 1103-1113 (2019). https://doi. org/10.1002/aocs.12264

14. Wang, Z.G., Zhang, C., Zhang, T., Ju, X.R., He, R.: Effects of acylation and glycation treatments on physicochemical and gelation properties of rapeseed protein isolate. RSC Adv. 8(70), 40395-40406 (2018). https://doi.org/10.1039/c8ra07912a

15. Sánchez-Vioque, R., Bagger, C.L., Larré, C., Guéguen, J.: Emulsifying properties of acylated rapeseed (Brassica napus L.) peptides. J. Colloid Interface Sci. 271(1), 220-226 (2004). https://doi. org/10.1016/j.jcis.2003.10.028

16. Krause, J.P.: Comparison of the effect of acylation and phosphorylation on surface pressure, surface potential and foaming properties of protein isolates from rapeseed (Brassica napus). Ind. Crops Prod. 15(3), 221-228 (2002). https://doi.org/10.1016/s0926 $-6690(01) 00117-0$
17. Sanchez-Vioque, R., Bagger, C.L., Rabiller, C., Gueguen, J.: Foaming properties of acylated rapeseed (Brassica napus L.) hydrolysates. J. Colloid Interface Sci. 244(2), 386-393 (2001). https:// doi.org/10.1006/jcis.2001.7932

18. Malabat, C., nchez-Vioque, R.I.S., Rabiller, C., Gu guen, J.: Emulsifying and foaming properties of native and chemically modified peptides from the $2 \mathrm{~S}$ and $12 \mathrm{~S}$ proteins of rapeseed (Brassica napus L.). J. Am. Oil Chem. Soc. 78(3), 235-242 (2001). https://doi. org/10.1007/s11746-001-0251-x

19. Schotten, C.: Ueber die Oxydation des Piperidins. Ber. Dtsch. Chem. Ges. 17(2), 2544-2547 (1884). https://doi.org/10.1002/cber.18840 1702178

20. Baumann, E.: Ueber eine einfache Methode der Darstellung von Benzoësäureäthern. Ber. Dtsch. Chem. Ges. 19(2), 3218-3222 (1886). https://doi.org/10.1002/cber.188601902348

21. Association of Official Analytical Chemists (AOAC): AOAC: Protein (crude) in animal feed. Official methods of analysis of the Association of Analytical Chemists (AOAC) 15 Ed. In. (1990)

22. Mahmoud, M.A.A., Tybussek, T., Loos, H.M., Wagenstaller, M., Buettner, A.: Odorants in fish feeds: a potential source of malodors in aquaculture. Front. Chem. (2018). https://doi.org/10.3389/fchem .2018 .00241

23. Morr, C.V., German, B., Kinsella, J.E., Regenstein, J.M., Buren, J.P.V., Kilara, A., Lewis, B.A., Mangino, M.E.: A collaborative study to develop a standardized food protein solubility procedure. J. Food Sci. 50(6), 1715-1718 (1985). https://doi. org/10.1111/j.1365-2621.1985.tb10572.x

24. Fetzer, A., Herfellner, T., Eisner, P.: Rapeseed protein concentrates for non-food applications prepared from pre-pressed and coldpressed press cake via acidic precipitation and ultrafiltration. Ind. Crops Prod. 132, 396-406 (2019). https://doi.org/10.1016/j.inder op.2019.02.039

25. Schmid, M.: Properties of cast films made from different ratios of whey protein isolate, hydrolysed whey protein isolate and glycerol. Materials (Basel, Switzerland) 6(8), 3254-3269 (2013). https://doi. org/10.3390/ma6083254

26. Kaelble, D.H.: Dispersion-polar surface tension properties of organic solids. J. Adhes. 2(2), 66-81 (1970). https://doi.org/10.1080/00218 46708544582

27. Rabel, W.: Einige Aspekte der Benetzungstheorie und ihre Anwendung auf die Untersuchung und Veränderung der Oberflächeneigenschaften von Polymeren. Farbe und Lacke 77(10), 997-1005 (1971)

28. Owens, D.K., Wendt, R.C.: Estimation of the surface free energy of polymers. J. Appl. Polym. Sci. 13(8), 1741-1747 (1969). https://doi. org/10.1002/app.1969.070130815

29. Deutsches Institut für Normung e.V.: DIN 53380-3. In: Bestimmung der Gasdurchlässigkeit. Berlin, Germany (1998)

30. Nielsen, P.M., Petersen, D., Dambmann, C.: Improved method for determining food protein degree of hydrolysis. J. Food Sci. 66(5), 642-646 (2001). https://doi.org/10.1111/j.1365-2621.2001.tb046 14.X

31. Frister, H., Meisel, H., Schlimme, E.: OPA method modified by use of N,N-dimethyl-2-mercaptoethylammonium chloride as thiol component. Fresenius' Zeitschrift Für Analytische Chemie 330(7), 631-633 (1988). https://doi.org/10.1007/bf00473782

32. Adler-Nissen, J.: Enzymic Hydrolysis of Food Proteins. Elsevier Applied Science Publishers, New York (1986)

33. Vieira, M.G.A., da Silva, M.A., dos Santos, L.O., Beppu, M.M.: Natural-based plasticizers and biopolymer films: a review. Eur. Polymer J. 47(3), 254-263 (2011). https://doi.org/10.1016/j.eurpo lymj.2010.12.011

34. Schmid, M., Sängerlaub, S., Wege, L., Stäbler, A.: Properties of transglutaminase crosslinked whey protein isolate coatings and cast 
films. Packag. Technol. Sci. 27(10), 799-817 (2014). https://doi. org/10.1002/pts.2071

35. Li, S.Z., Donner, E., Thompson, M., Zhang, Y.C., Rempel, C., Liu, Q.: Preparation and characterization of cross-linked canola protein isolate films. Eur. Polymer J. 89, 419-430 (2017). https://doi. org/10.1016/j.eurpolymj.2017.03.001

36. Galus, S., Kadzińska, J.: Whey protein edible films modified with almond and walnut oils. Food Hydrocolloids 52, 78-86 (2016). https ://doi.org/10.1016/j.foodhyd.2015.06.013

37. Wang, Z., Zhou, J., Wang, X.-X., Zhang, N., Sun, X.-X., Ma, Z.-S.: The effects of ultrasonic/microwave assisted treatment on the water vapor barrier properties of soybean protein isolate-based oleic acid/ stearic acid blend edible films. Food Hydrocolloids 35, 51-58 (2014). https://doi.org/10.1016/j.foodhyd.2013.07.006

38. Ma, W., Tang, C.-H., Yin, S.-W., Yang, X.-Q., Wang, Q., Liu, F., Wei, Z.-H.: Characterization of gelatin-based edible films incorporated with olive oil. Food Res. Int. 49(1), 572-579 (2012). https:// doi.org/10.1016/j.foodres.2012.07.037

39. Javanmard, M., Golestan, L.: Effect of olive oil and glycerol on physical properties of whey protein concentrate films. J. Food
Process Eng. 31(5), 628-639 (2008). https://doi.org/10.111 1/j.1745-4530.2007.00179.x

40. Fernández, L., de Apodaca, E.D., Cebrián, M., Villarán, M.C., Maté, J.I.: Effect of the unsaturation degree and concentration of fatty acids on the properties of WPI-based edible films. Eur. Food Res. Technol. 224(4), 415-420 (2007). https://doi.org/10.1007/s00217-006-0305-1

41. Jiménez, A., Fabra, M.J., Talens, P., Chiralt, A.: Effect of lipid self-association on the microstructure and physical properties of hydroxypropyl-methylcellulose edible films containing fatty acids. Carbohydr. Polym. 82(3), 585-593 (2010). https://doi.org/10.1016/j. carbpol.2010.05.014

Publisher's Note Springer Nature remains neutral with regard to jurisdictional claims in published maps and institutional affiliations. 